\section{Salt Tolerance of Tomato Plants as Affected by Stage of Plant Development}

\author{
F.M. del Amor, V. Martinez ${ }^{1}$, and A. Cerdá \\ Dept. of Plant Physiology and Nutrition, Centro de Edafologia y Biologia \\ Aplicada del Segura (CSIC), P.O. Box 4195, 30080 Murcia, Spain
}

Additional index words. perlite, soilless culture, salinity, tomato

\begin{abstract}
In order to simulate the usage of brackish irrigation water in greenhouse tomato (Lycopersicum esculentum Mill. cv. Daniela) culture in perlite, plants were supplied with nutrient solutions containing $0,20,40$, and $60 \mathrm{~mm}$ NaCl. The three highest salinity treatments were applied at three different plant growth stages, during early vegetative growth [16 days after transplanting, (DAT)], beginning of flowering (36 DAT), and starting fruit development (66 DAT). Salt tolerance of tomato plants increased when the application of salinity was delayed. Salinity significantly decreased size and number of marketable fruits, but increased fruit quality by increasing total soluble solids and sugar content. Leaf and fruit calcium and potassium concentrations were decreased significantly by increasing salinity levels. This was compensated for the accumulation of sodium. Anion accumulation was increased by increasing chloride concentration. These results indicate that it is feasible to use brackish water for growing tomato with minimum yield losses if salt concentration and duration of exposure are carefully monitored.
\end{abstract}

Valuable agriculture/food production in arid and semiarid regions of the world, which depends on irrigation, faces a serious challenge because it must increase or at least maintain crop productivity while coping with ever more saline irrigation waters. The success of using such waters needs advances in the knowledge of the many factors involved in plant salt tolerance (Maas and Hoffman, 1977). The markets demand horticultural crops of high quality throughout the year, which encourages farmers to grow crops in artificial substrates and in greenhouses. Under proper management, soilless culture will permit use of low quality waters, since it is more feasible to control salt concentration in the root media by establishing the appropriate leaching fraction.

Worldwide, tomato is one of the most important horticultural crops. The effect of salinity on fruit yield and quality has been investigated using different substrates, such as soils (Martinez et al., 1987; Mitchell et al., 1991a; Shalhevet and Yaron, 1973), solution cultures (Cerdá et al., 1977), coarse sand (Mizrahi et al., 1988), peat-loam (Sharaf and Hobson, 1986), nutrient film system (Adams and Ho, 1989; Gough and Hobson, 1990) and rockwool (Adams, 1991), but there are no data on perlite.

Crop salt tolerance is influenced by several factors. The growth stages at which salinization is initiated, the final level of salinity achieved, and the portion of the plant to be

Received for publication 18 July 2000. Accepted for publication 30 Mar. 2001. This study was supported by the Comisión Interministerial de Ciencia y Tecnología Project AMB95-0135. We thank Javier Abrisqueta for technical assistance.

${ }^{1}$ To whom requests for reprints should be addressed. E-mail address: vicente@cebas.csic.es marketed (Lunin et al., 1963). Cultivar differences must also be considered in evaluating crop salt tolerance, since many crops are developed from a diverse genetic base (Maas and Hoffman, 1977). In soilless culture, the physical properties of the substrate may influence salt tolerance, and consequently crop production and fruit quality (Kuehny and Morales, 1998).

This paper describes a water management strategy, by exploring the response of tomato to saline water applied at different development stage, and by establishing the maximum salt concentration in the irrigation water to maintain crop productivity.

The objective of our study was to determine the effect of different degrees of salinity in the irrigation solution, applied at different growth stages, on vegetative growth, fruit yield and quality, and fruit and leaf mineral composition.

\section{Materials and Methods}

Tomato (Lycopersicum esculentum Mill. cv. Daniela) plants were grown in perlite bags, $1.2 \mathrm{~m}$ long and $20 \mathrm{~cm}$ high, in a greenhouse equipped with a computer regulated system for drip irrigation, under controlled environmental conditions. During the experiment, the daytime temperature was maintained between 20 to $30^{\circ} \mathrm{C}$ and the nighttime temperature was never lower than $15^{\circ} \mathrm{C}$. The relative humidity $(\mathrm{RH})$ was $55 \%$ throughout the day, whereas at night it reached $75 \%$. The plants were transplanted on 19 Jan. 1998, and irrigated with a basic nutrient solution of the following macronutrient composition (mM): $\mathrm{NO}_{3}^{-}, 14 ; \mathrm{H}_{2} \mathrm{PO}_{4}^{-}, 1.5 ; \mathrm{SO}_{4}{ }^{2-}, 1.5 ; \mathrm{Ca}^{2+}, 4 ; \mathrm{K}^{+}$, 7.5; and $\mathrm{Mg}^{2+}$, 1.5. Micronutrient concentrations were (in $\mu \mathrm{M}$ ): $\mathrm{Fe}, 17.9 ; \mathrm{Mn}, 9.1 ; \mathrm{Zn}, 7.6$; $\mathrm{B}, 23.3 ; \mathrm{Cu}, 0.31$; and $\mathrm{Mo}, 0.1$. The $\mathrm{pH}$ of the solution was adjusted to 5.6 with $\mathrm{HNO}_{3}$. The plants were irrigated according to the demand detected in the appropriate trays, with an excess of $25 \%$ estimated from the control plots. Three irrigation drippers were placed in each perlite bag.

The treatments consisted of a control $\left(2 \mathrm{dS} \cdot \mathrm{m}^{-1}\right)$ plus three salinity levels $(4,6$, and $8 \mathrm{dS} \cdot \mathrm{m}^{-1}$ ) in the irrigation solution. The three salinity levels were reached by adding 20,40 , and $60 \mathrm{~mm} \mathrm{NaCl}$ to the basic nutrient solution (control). The three salinity levels were applied at three different growth stages, $16 \mathrm{~d}$ after transplanting (DAT), 36 DAT (after flowering of the first cluster) and 66 DAT (starting fruit development). Thus, there were 10 different treatments (three salinity levels $\times$ three times plus the control). The experiment was arranged as a factorial design in two randomised blocks, each containing the 10 treatments. Each treatment had three perlite bags with six plants per bag (18 plants per treatment and per block).

Once a week, selective picking of ripe fruit was carried out from 29 Apr. to the end of the experiment, 6 June. The individual fruits of each truss were counted and weighed. Marketable fruits were considered as those above $50 \mathrm{~g}$. Dry matter percentage after $48 \mathrm{~h}$ at $65^{\circ} \mathrm{C}$ in a ventilated oven was determined. This material was used to determine the mineral content of fruits. Before destructive analyses of the fruit, the firmness was determined on fruit with intact skin by using a Bertuzzi FT01 1 penetrometer (Alfonsine, Italy), fitted with an 8-mm-diameter probe, and the surface color characters $L, a$ and $b$ were determined in a Minolta model CR300 colorimeter (Minolta Co., Ramsey, N.J.). Quality constituents were determined on filtrates of blended samples. Soluble solids were evaluated by an Atago N1 refractometer and expressed as ${ }^{\circ}$ Brix at $20^{\circ} \mathrm{C}$. Acidity was determined by potentiometric titration with $0.1 \mathrm{~m} \mathrm{NaOH}$ to $\mathrm{pH} 8.1$, using 20 $\mathrm{mL}$ of juice) and reducing sugars by the anthrone method (Hewitt, 1958).

The uppermost fully expanded leaves were sampled at the end of the experiment (114 DAT) and oven dried at $65^{\circ}$ for $48 \mathrm{~h}$. Chemical analyses of leaves and fruit samples were carried out after digestion with nitric and perchloric acids $(2: 1) . \mathrm{Na}^{+}, \mathrm{K}^{+}, \mathrm{Ca}^{2+}$, and $\mathrm{Mg}^{2+}$ were determined by atomic absorption spectrometry (Perkin-Elmer 5500, Norwalk, Conn.). Chloride and $\mathrm{NO}_{3}-\mathrm{N}$ were extracted from $50 \mathrm{mg}$ of ground material with $10 \mathrm{~mL}$ of deionized water. Chloride was measured by electrometric titration with a Corning chloride Analyzer 926, whereas $\mathrm{NO}_{3}-\mathrm{N}$ was determined by the difference between the absorption at 210 and $270 \mathrm{~nm}$ in a spectrophotometer.

Vegetative and fruit yield components, fruit quality constituents and leaf and fruit mineral composition data were subjected to analysis of variance (ANOVA) using the SPSS computer package (SPSS, 1985).

Salt tolerance was determined by adjusting the data with nonlinear regression using the sigmoidal model of Van Genuchten (1983), where $\mathrm{Yr}=\mathrm{Ym} /\left[1+\left(\mathrm{C} / \mathrm{C}_{50}\right)^{3}\right], \mathrm{Yr}$ is the 
relative yield, $\mathrm{Ym}$ the maximum yield, $\mathrm{C}$ the electric conductivity and $C_{50}$ the electric conductivity that results in a yield reduction of $50 \%$.

\section{Results}

Yield. According to the Van Genuchten model (1983) salt tolerance was higher at the 66 DAT treatment $\left(\mathrm{C}_{50}=8.79 \mathrm{dS} \cdot \mathrm{m}^{-1}\right)$ than at $36\left(\mathrm{C}_{50}=7.99 \mathrm{dS} \cdot \mathrm{m}^{-1}\right)$ or $16 \mathrm{DAT}\left(\mathrm{C}_{50}=7.48\right.$ $\mathrm{dS} \cdot \mathrm{m}^{-1}$ ) (Fig. 1). In the three salinization times, the model fitted significantly the experiment data $(P<0.05$, according to ANOVA of the regression). Salinity reduced the total marketable fruit yield and the number of fruits of the first 9 trusses (Table 1). The effect of salinity applied at 16 DAT on the final yield was greater than when applied 36 and 66 DAT. The total number and size of marketable fruits were also significantly reduced by salinity but not by the salinization time. Thus, the changes in fruit yield as a function of salinity are due to a decrease in both number and size of the fruit. Higher salinity, but not salinization time, significantly increased the dry matter percentage of the fruit. Trusses 1 to 3 produced a higher yield than trusses 7 to 9 . This effect of salinity on fruit yield parameters was more pronounced in the higher than in the lower trusses.

The unmarketable fruit yield (Table 2) increased progressively with salinity. However the highest unmarketable fruit yield was obtained when salinity was applied at 36 DAT (beginning of flowering). The incidence of fruits with blossom end rot (BER) in this study increased significantly with salinity on trusses 1 to 3 and 7 to 9 , where the number of fruits with BER varied from 3 to 5 per plant. The number of fruits with BER in trusses 1 to 3 was significantly higher when salinity was applied at 36 DAT than at 16 or 66 DAT. Total shoot biomass at the end of the experiment was significantly reduced by salinity, although this effect varied with the time when salinity was applied.

Fruit quality. In general, regardless of the salinization time treatments, fruits from salt treated plants showed significant increases in concentration of sugars, total soluble solids and total acid content, whereas fruit $\mathrm{pH}$ decreased (Table 3 ). The firmness, measured on fruit with intact skin, showed a tendency to increase with salinity levels. Within the surface color parameters, the red color (a) tended to increase with salinity levels, whereas the yellow color (b) and the lightness (L) were not affected by salinity levels.

Fruit nutrient content. No significant differences were found for total cation accumulation $\left(\mathrm{Na}^{+}, \mathrm{K}^{+}, \mathrm{Ca}^{2+}\right.$, and $\left.\mathrm{Mg}^{2+}\right)$ on a dry weight basis in mature fruit from trusses 1 to 3 (Table 4). However, total anion $\left(\mathrm{Cl}^{-}\right.$and $\mathrm{NO}_{3}^{-}$) concentration increased by $11 \%$ as salinity level increased from 2 to $8 \mathrm{dS} \cdot \mathrm{m}^{-1}$. Fruit $\mathrm{K}^{+}$content, which represented the major contribution to total ion accumulation, was reduced significantly by salinity levels. This reduction in $\mathrm{K}^{+}$concentration was in part compensated for the accumulation of
$\mathrm{Na}^{+}, \mathrm{Ca}^{2+}$, and $\mathrm{Mg}^{2+}$ were also decreased significantly by salinity levels. The content of both $\mathrm{Ca}^{2+}$ and $\mathrm{Mg}^{2+}$ decreased from truss 1 to 3 , particularly under salinity treatments (data not shown). Chloride accumulation increased with salinity level, but the values were never double those of control. The fruit $\mathrm{NO}_{3}{ }^{-}$content was slightly decreased by salinity.

Leaf mineral composition. The leaf $\mathrm{Na}^{+}$and $\mathrm{Cl}^{-}$contents increased significantly with increasing salinity level, particularly $\mathrm{Cl}^{-}$, although the leaf contents of both $\mathrm{Na}^{+}$and $\mathrm{Cl}^{-}$decreased as salinization time was delayed (Table 5). Leaf $\mathrm{K}^{+}$and $\mathrm{Ca}^{2+}$ concentrations were significantly reduced by increasing salinity, especially when it was initiated 16 DAT. Leaf $\mathrm{Mg}^{2+}$ contents were unaffected by salinity.

\section{Discussion}

Salt tolerance of tomato increased when salinity treatments were applied at later plant

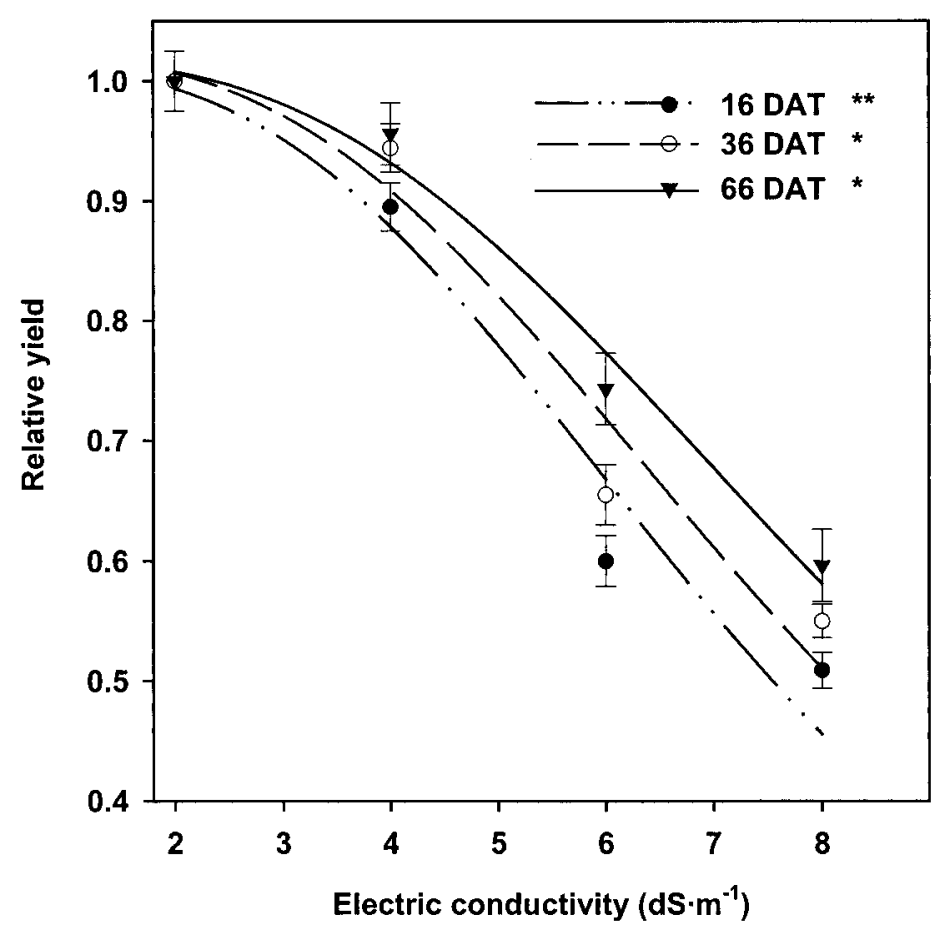

Fig. 1. Salt tolerance of tomato plants as affected by salinization time. Data were adjusted by a non-linear regression using the sigmoidal model of Van Genuchten (1983). Each point is the mean value of 36 plants.

${ }^{*},{ }^{* *}$ Significant at $P<0.05$ and $P<0.01$ respectively, according to analysis of variance of the regression.

Table 1. Effects of salinity and time of salinization on marketable tomato ruit yield parameters.

\begin{tabular}{|c|c|c|c|c|c|c|c|}
\hline \multicolumn{2}{|c|}{ Treatments } & \multicolumn{6}{|c|}{ Marketable fruit ( $>50 \mathrm{~g}$ ) yield parameters } \\
\hline \multirow{2}{*}{$\begin{array}{l}\text { Salinization } \\
\text { time (DAT) }\end{array}$} & \multirow{2}{*}{$\begin{array}{c}\mathrm{EC} \\
\left(\mathrm{dS} \cdot \mathrm{m}^{-1}\right)\end{array}$} & \multirow{2}{*}{$\begin{array}{l}\text { No. } \\
\text { fruits }\end{array}$} & \multirow{2}{*}{$\begin{array}{c}\text { Mean fruit } \\
\text { wt }(\mathrm{g})\end{array}$} & \multirow{2}{*}{$\begin{array}{c}\text { Dry wt } \\
(\%)\end{array}$} & \multicolumn{3}{|c|}{ Trusses $\left(\mathrm{kg} \cdot\right.$ plant $\left.^{-1}\right)$} \\
\hline & & & & & $1-3$ & $1-6$ & $1-9$ \\
\hline \multirow[t]{4}{*}{$\overline{16}$} & 2 (Control) & 68 & 123 & 6.3 & $4.28 \mathrm{a}$ & $6.51 \mathrm{a}$ & 8.40 \\
\hline & 4 & 69 & 109 & 6.4 & $3.02 \mathrm{c}$ & $5.40 \mathrm{c}$ & 7.52 \\
\hline & 6 & 52 & 97 & 7.8 & $2.50 \mathrm{de}$ & $4.63 \mathrm{~d}$ & 5.04 \\
\hline & 8 & 53 & 79 & 8.7 & $1.95 \mathrm{f}$ & $3.86 \mathrm{f}$ & 4.28 \\
\hline \multirow[t]{3}{*}{36} & 4 & 72 & 110 & 7.1 & $2.94 \mathrm{~cd}$ & $6.04 \mathrm{~b}$ & 7.93 \\
\hline & 6 & 65 & 85 & 7.6 & $2.59 \mathrm{~d}$ & $5.21 \mathrm{c}$ & 5.50 \\
\hline & 8 & 58 & 80 & 8.6 & $2.26 \mathrm{e}$ & $4.03 \mathrm{f}$ & 4.62 \\
\hline \multirow[t]{3}{*}{66} & 4 & 75 & 107 & 6.8 & $3.38 \mathrm{~b}$ & $6.25 \mathrm{ab}$ & 8.03 \\
\hline & 6 & 66 & 94 & 7.5 & $2.58 \mathrm{~d}$ & $5.42 \mathrm{c}$ & 6.24 \\
\hline & 8 & 60 & 84 & 8.0 & $2.24 \mathrm{ef}$ & $4.37 \mathrm{e}$ & 5.01 \\
\hline \multicolumn{8}{|c|}{ Main factor } \\
\hline \multirow{3}{*}{ Salinity } & 4 & $72 \mathrm{a}$ & $109 \mathrm{a}$ & $6.8 \mathrm{c}$ & $3.11 \mathrm{a}$ & $5.90 \mathrm{a}$ & $7.83 \mathrm{a}$ \\
\hline & 6 & $61 \mathrm{~b}$ & $92 \mathrm{~b}$ & $7.6 \mathrm{~b}$ & $2.56 \mathrm{~b}$ & $5.09 \mathrm{~b}$ & $5.59 \mathrm{~b}$ \\
\hline & 8 & $57 \mathrm{~b}$ & $81 \mathrm{c}$ & $8.4 \mathrm{a}$ & $2.15 \mathrm{c}$ & $4.09 \mathrm{c}$ & $4.64 \mathrm{c}$ \\
\hline \multirow[t]{3}{*}{ Time (DAT) } & 16 & 58 & 95 & 7.6 & $2.49 \mathrm{~b}$ & $4.63 \mathrm{c}$ & $5.61 \mathrm{c}$ \\
\hline & 36 & 65 & 92 & 7.8 & $2.60 \mathrm{~b}$ & $5.09 \mathrm{~b}$ & $6.02 \mathrm{~b}$ \\
\hline & 66 & 67 & 95 & 7.4 & $5.35 \mathrm{a}$ & $5.35 \mathrm{a}$ & $6.43 \mathrm{a}$ \\
\hline \multicolumn{8}{|c|}{ Analysis of variance } \\
\hline Salinity & & $* * *$ & $* * *$ & $* * *$ & $* * *$ & $* * *$ & $* * *$ \\
\hline Time & & NS & NS & NS & $* * *$ & $* * *$ & $* *$ \\
\hline Salinity $\times$ time & & NS & NS & NS & * & $*$ & NS \\
\hline
\end{tabular}

${ }^{*, * *, * * *}$ Significant differences between means at the $5 \%, 1 \%$, and $0.1 \%$ level of probability. Ns $=$ nonsignificant at $P=5 \%$. Means with different letters indicate significant differences $(P<0.05)$ by Tukey's test. 
development stages (Fig. 1). In addition, the results from Table 1 show that in a commercial greenhouse it is possible to improve fruit quality of tomato, grown in perlite as substrate, without significant yield loss by using an irrigation solution of $4 \mathrm{dS} \cdot \mathrm{m}^{-1}$ applied at $16 \mathrm{DAT}$. A similar result was reported by Mizrahi et al. (1988) for $3 \mathrm{dS} \cdot \mathrm{m}^{-1}$ with tomato grown in sand culture. The irrigation of tomato with water of $6 \mathrm{dS} \cdot \mathrm{m}^{-1}$ was uneconomical, since yield decreased $\approx 30 \%$, even when salinity was applied at 66 DAT. However, Mitchell et al. (1991a) found that it is possible to irrigate tomato grown in soil cultures with water of $8 \mathrm{dS} \cdot \mathrm{m}^{-1}$

with only a minor yield reduction. The differences with our results may be due to the fact that some tomato cultivars are more sensitive than others (Martinez et al. 1987), and also to the type of culture used, which could be a limiting factor that minimizes the negative effect of salinity with respect to the control treatment.

Fruit yield reduction, under saline conditions, was lower with decreasing time of salt exposure, regardless of salinity level (Fig. 1) as also found by Adams and Ho (1989). The reduction of fruit yield by salinity was due to a reduction in both size and number of fruits.

Table 2. Effect of salinity and time of salinization on unmarketable tomato fruit yield, incidence of fruit with BER and shoot biomass.

\begin{tabular}{|c|c|c|c|c|c|c|}
\hline \multicolumn{2}{|c|}{ Treatments } & \multirow{3}{*}{$\begin{array}{l}\text { Unmarketable fruit } \\
\begin{array}{c}(<50 \mathrm{~g}) \text { yield } \\
\left(\mathrm{kg} \cdot \text { plant }^{-1}\right)\end{array}\end{array}$} & \multirow{2}{*}{\multicolumn{3}{|c|}{$\frac{\text { No. fruits with BER per plant }}{\text { Trusses }}$}} & \multirow{3}{*}{$\begin{array}{r}\text { Shoot } \\
\text { biomass } \\
(\mathrm{g})\end{array}$} \\
\hline \multirow{2}{*}{$\begin{array}{l}\text { Salinization } \\
\text { time (DAT) }\end{array}$} & \multirow{2}{*}{$\begin{array}{c}\mathrm{EC} \\
\left(\mathrm{dS} \cdot \mathrm{m}^{-1}\right)\end{array}$} & & & & & \\
\hline & & & $1-3$ & $4-6$ & $7-9$ & \\
\hline \multirow[t]{4}{*}{16} & 2 (Control) & 0.33 & 1.13 & 2.13 & 2.27 & 2555 \\
\hline & 4 & 0.31 & 1.25 & 2.50 & 3.75 & 2293 \\
\hline & 6 & 0.75 & 2.50 & 3.67 & 4.00 & 2020 \\
\hline & 8 & 0.61 & 3.29 & 2.43 & 5.13 & 1640 \\
\hline \multirow[t]{3}{*}{36} & 4 & 0.68 & 2.43 & 3.8 & 3.20 & 2001 \\
\hline & 6 & 0.64 & 2.67 & 3.5 & 3.67 & 2271 \\
\hline & 8 & 0.80 & 2.80 & 4.75 & 4.80 & 1672 \\
\hline \multirow[t]{3}{*}{66} & 4 & 0.41 & 2.00 & 2.83 & 4.00 & 2639 \\
\hline & 6 & 0.46 & 1.33 & 3.13 & 4.75 & 2060 \\
\hline & 8 & 0.53 & 2.50 & 3.2 & 4.00 & 1975 \\
\hline \multicolumn{7}{|c|}{ Main factor } \\
\hline \multirow[t]{3}{*}{ Salinty } & 4 & $0.47 \mathrm{~b}$ & $1.89 \mathrm{c}$ & 3.04 & $3.65 \mathrm{c}$ & $2311 \mathrm{a}$ \\
\hline & 6 & $0.62 \mathrm{a}$ & $2.17 \mathrm{~b}$ & 3.43 & $4.14 \mathrm{~b}$ & $2117 \mathrm{~b}$ \\
\hline & 8 & $0.65 \mathrm{a}$ & $2.86 \mathrm{a}$ & 3.46 & $4.64 \mathrm{a}$ & $1762 \mathrm{c}$ \\
\hline \multirow[t]{3}{*}{ Time (DAT) } & 16 & $0.56 \mathrm{~b}$ & 2.35 & 2.87 & 4.29 & $1984 \mathrm{~b}$ \\
\hline & 36 & $0.71 \mathrm{a}$ & 2.63 & 4.02 & 3.89 & $1981 \mathrm{~b}$ \\
\hline & 66 & $0.47 \mathrm{~b}$ & 1.94 & 3.05 & 4.25 & $2225 \mathrm{a}$ \\
\hline \multicolumn{7}{|c|}{ Analysis of variance } \\
\hline \multicolumn{2}{|l|}{ Salinity } & $* * *$ & $* *$ & NS & $*$ & **** \\
\hline \multicolumn{2}{|l|}{ Time } & **** & NS & NS & NS & $*$ \\
\hline \multicolumn{2}{|l|}{ Salinity $\times$ time } & NS & NS & NS & NS & NS \\
\hline
\end{tabular}

$\overline{*, * * * * * * \text { Significant differences between means at the } 5 \%, 1 \% \text { and } 0.1 \% \text { level of probability. NS }=\text { nonsignificant }}$ at $P=5 \%$. Means with different letters indicate significant differences $(P<0.05)$ by Tukey's test.
The reduction in fruit water content resulted in an increase of fruit dry matter percentage (Table 1).

These data also show that the effect of salinity on tomato fruit size varies according to the position of the trusses on the stem. The number and size of the tomato fruits decreased with increasing height of the truss on the stem (Table 1). This agrees with the data of Bertin (1995), who reported that the final size of distal fruits is lower than that of proximal fruits, and with the result of Bangerth and $\mathrm{Ho}$ (1984), which indicated that distal fruits have a lower sink strength than proximal fruits. Therefore, our data support the hypothesis of Lunin et al. (1963), that plant salt response changes with time of salt exposure, salinity level used and with the part of the yield considered.

Improvement of fruit quality parameters with salinity, using different substrates, is well known (Mizrahi et al. 1988; Adams and Ho, 1989; Adams, 1991; Petersen et al. 1998). The increase of soluble solids (Table 3 ) seems to be associated with the reduction in the water content of the fruit (Adams and Ho, 1989) and with the increase in soluble sugar accumulation (Mitchell et al. 1991b). Fruit acidity has been related to the fruit $\mathrm{K}^{+}$content (Voogt, 1988; Adams, 1991; Adams and Ho, 1993). However, our data show that the $\mathrm{K}$ content (Table 4) in the fruit decreased with increasing salinity, whereas fruit juice acidity increased. Thus, the increase in acidity of the fruit juice could be due to the higher $\mathrm{Na}^{+}$and/or $\mathrm{Cl}^{-}$ contents in the fruit juice since these are the only ions that increase with salinity. Adams (1991) suggested that much of the increase in the acidity of the juice is due to salinity rather than to $\mathrm{K}^{+}$per se. The content of $\mathrm{Ca}^{2+}$ in the fruit decreased with salinity (Table 4 ) and this decrease was more evident in fruits from the highest truss rather than from the lowest one

Table 3. Effect of salinity and time of salinization on tomato fruit quality parameters.

\begin{tabular}{|c|c|c|c|c|c|c|c|c|c|}
\hline \multicolumn{2}{|c|}{ Treatment } & \multirow{3}{*}{$\begin{array}{l}\text { Firmness } \\
(\mathrm{N})\end{array}$} & \multirow{2}{*}{\multicolumn{3}{|c|}{ Color }} & \multirow{3}{*}{$\begin{array}{l}\text { Sugars } \\
\left(\mathrm{g} \cdot \mathrm{L}^{-1}\right)\end{array}$} & \multirow{3}{*}{$\begin{array}{c}\text { TSS } \\
\left({ }^{\circ} \text { Brix }\right)\end{array}$} & \multirow{3}{*}{$\begin{array}{c}\text { Acidity } \\
(\% \text { citric })\end{array}$} & \multirow[b]{3}{*}{$\mathrm{pH}$} \\
\hline \multirow{2}{*}{$\begin{array}{l}\text { Salinization } \\
\text { time (DAT) }\end{array}$} & \multirow{2}{*}{$\begin{array}{c}\mathrm{EC} \\
\left(\mathrm{dS} \cdot \mathrm{m}^{-1}\right)\end{array}$} & & & & & & & & \\
\hline & & & $\mathrm{a}$ & $\mathrm{b}$ & $\mathrm{L}$ & & & & \\
\hline \multirow{4}{*}{16} & 2 (Control) & 6.51 & $18.8 \mathrm{~cd}$ & $33.1 \mathrm{~cd}$ & 46.2 & 83.5 & 5.69 & 0.21 & 4.34 \\
\hline & 4 & 7.15 & $18.5 \mathrm{~d}$ & $33.8 \mathrm{~b}$ & 46.5 & 83.9 & 6.44 & 0.24 & 4.35 \\
\hline & 6 & 7.22 & $19.3 \mathrm{bcd}$ & $33.3 \mathrm{bc}$ & 46.0 & 85.8 & 7.29 & 0.28 & 4.30 \\
\hline & 8 & 7.19 & $20.1 \mathrm{~b}$ & $35.8 \mathrm{a}$ & 47.8 & 120.4 & 9.90 & 0.35 & 4.25 \\
\hline \multirow[t]{3}{*}{36} & 4 & 6.33 & $18.4 \mathrm{~d}$ & $33.0 \mathrm{~cd}$ & 46.0 & 75.4 & 6.27 & 0.24 & 4.33 \\
\hline & 6 & 7.07 & $19.5 \mathrm{bc}$ & $33.3 \mathrm{bc}$ & 46.5 & 91.0 & 8.07 & 0.26 & 4.26 \\
\hline & 8 & 6.63 & $19.0 \mathrm{~cd}$ & $32.8 \mathrm{~d}$ & 47.0 & 115 & 8.74 & 0.29 & 4.29 \\
\hline \multirow[t]{3}{*}{66} & 4 & 6.69 & $18.6 \mathrm{~cd}$ & $33.7 \mathrm{~b}$ & 45.7 & 95.9 & 5.76 & 0.21 & 4.31 \\
\hline & 6 & 7.48 & $18.9 \mathrm{~cd}$ & $33.2 \mathrm{bcd}$ & 46.5 & 98.5 & 6.94 & 0.25 & 4.35 \\
\hline & 8 & 7.09 & $22.2 \mathrm{a}$ & $33.0 \mathrm{~cd}$ & 45.9 & 121.4 & 8.39 & 0.28 & 4.31 \\
\hline \multicolumn{10}{|c|}{ Main Factor } \\
\hline \multirow[t]{3}{*}{ Salinity } & 4 & $6.72 \mathrm{c}$ & $18.50 \mathrm{c}$ & $33.50 \mathrm{ab}$ & $46.07 \mathrm{~b}$ & $85.1 \mathrm{~b}$ & $6.16 \mathrm{c}$ & $0.23 \mathrm{c}$ & $4.33 \mathrm{a}$ \\
\hline & 6 & $7.26 \mathrm{a}$ & $19.23 \mathrm{~b}$ & $33.27 \mathrm{~b}$ & $46.33 \mathrm{~b}$ & $91.8 \mathrm{~b}$ & $7.43 \mathrm{~b}$ & $0.26 \mathrm{~b}$ & $4.30 \mathrm{~b}$ \\
\hline & 8 & $6.97 \mathrm{~b}$ & $20.43 \mathrm{a}$ & $33.87 \mathrm{a}$ & $46.90 \mathrm{a}$ & $119.0 \mathrm{a}$ & $9.01 \mathrm{a}$ & $0.31 \mathrm{a}$ & $4.28 \mathrm{~b}$ \\
\hline \multirow{3}{*}{ Time (DAT) } & 16 & $7.19 \mathrm{a}$ & $19.30 \mathrm{~b}$ & 34.3 & 46.8 & $96.7 \mathrm{~b}$ & 7.88 & $0.29 \mathrm{a}$ & 4.30 \\
\hline & 36 & $6.68 \mathrm{~b}$ & $19.00 \mathrm{~b}$ & 33.0 & 46.5 & $93.8 \mathrm{~b}$ & 7.69 & $0.26 \mathrm{~b}$ & 4.29 \\
\hline & 66 & $7.09 \mathrm{a}$ & $19.90 \mathrm{a}$ & 33.3 & 46.0 & $105.3 \mathrm{a}$ & 7.03 & $0.25 \mathrm{~b}$ & 4.32 \\
\hline \multicolumn{10}{|c|}{ Analysis of variance } \\
\hline Salinity & & $* * *$ & $* * *$ & $*$ & $*$ & ** & $* * *$ & $* * *$ & * \\
\hline Time & & $* * *$ & $* *$ & NS & NS & $*$ & NS & $*$ & NS \\
\hline Salinity $\times$ time & & NS & $*$ & $* * *$ & NS & NS & NS & NS & NS \\
\hline
\end{tabular}

$\overline{*, * * * * * *}$ Significant differences between means at the $5 \%, 1 \%$ and $0.1 \%$ level of probability. NS $=$ nonsignificant at $P=5 \%$. Means with different letters indicate significant differences $(P<0.05)$ by Tukey's test. 
Table 4. Effect of salinity and time of salinization on tomato mineral content of fruit (meq $\left.\cdot \mathrm{kg}^{-1}\right)$ obtained from trusses $1-3$.

\begin{tabular}{|c|c|c|c|c|c|c|c|c|c|}
\hline \multicolumn{2}{|c|}{ Treatments } & & & & & & & & \\
\hline \multirow{2}{*}{$\begin{array}{l}\text { Salinization } \\
\text { time (DAT) }\end{array}$} & \multirow{2}{*}{$\begin{array}{c}\text { EC } \\
\left(\mathrm{dS} \cdot \mathrm{m}^{-1}\right)\end{array}$} & \multicolumn{8}{|c|}{ Mineral content of fruits } \\
\hline & & $\mathrm{Cl}$ & $\mathrm{NO}_{3}$ & $\sum$ An. & $\mathrm{Na}$ & $\mathrm{K}$ & $\mathrm{Ca}$ & $\mathrm{Mg}$ & $\overline{\sum \mathrm{Cat}}$ \\
\hline \multirow[t]{4}{*}{$\overline{16}$} & 2 (Control) & $164 \mathrm{f}$ & 630 & 794 & 12.2 & 857 & 191 & 23.2 & $\overline{1084}$ \\
\hline & 4 & $215 \mathrm{~d}$ & 619 & 834 & 25.1 & 839 & 171 & 22.3 & 1058 \\
\hline & 6 & $255 \mathrm{~b}$ & 606 & 861 & 44.7 & 800 & 137 & 21.6 & 1003 \\
\hline & 8 & $300 \mathrm{a}$ & 593 & 893 & 60.5 & 770 & 154 & 20.1 & 1005 \\
\hline \multirow{3}{*}{36} & 4 & $215 \mathrm{~d}$ & 624 & 839 & 27.4 & 816 & 165 & 22.1 & 1032 \\
\hline & 6 & $252 \mathrm{~b}$ & 616 & 868 & 44.4 & 797 & 155 & 21.2 & 1019 \\
\hline & 8 & $293 \mathrm{a}$ & 605 & 898 & 67.3 & 758 & 146 & 20.3 & 992 \\
\hline \multirow[t]{3}{*}{66} & 4 & $199 \mathrm{e}$ & 621 & 820 & 29.9 & 857 & 166 & 23.1 & 1077 \\
\hline & 6 & $213 \mathrm{~d}$ & 609 & 822 & 38.4 & 836 & 152 & 21.5 & 1049 \\
\hline & 8 & $226 \mathrm{c}$ & 590 & 816 & 50.8 & 781 & 148 & 21.4 & 1002 \\
\hline \multicolumn{10}{|c|}{ Main Factor } \\
\hline \multirow[t]{3}{*}{ Salinity } & 4 & $210 \mathrm{c}$ & $621 \mathrm{a}$ & 831 & $27.5 \mathrm{c}$ & $838 \mathrm{a}$ & $168 \mathrm{a}$ & $22.5 \mathrm{a}$ & 1056 \\
\hline & 6 & $240 \mathrm{~b}$ & $610 \mathrm{ab}$ & 850 & $42.5 \mathrm{~b}$ & $811 \mathrm{a}$ & $149 \mathrm{~b}$ & $21.4 \mathrm{ab}$ & 1024 \\
\hline & 8 & $273 \mathrm{a}$ & $596 \mathrm{~b}$ & 869 & $59.5 \mathrm{a}$ & $770 \mathrm{~b}$ & $150 \mathrm{~b}$ & $20.6 \mathrm{~b}$ & 1000 \\
\hline \multirow[t]{3}{*}{ Time (DAT) } & 16 & $257 \mathrm{a}$ & 606 & 863 & $43.4 \mathrm{ab}$ & 803 & 154 & 21.3 & 1022 \\
\hline & 36 & $254 \mathrm{a}$ & 615 & 869 & $46.4 \mathrm{a}$ & 791 & 156 & 21.2 & 101 \\
\hline & 66 & $213 b$ & 607 & 820 & $39.7 \mathrm{~b}$ & 825 & 156 & 22.0 & 1043 \\
\hline \multicolumn{10}{|c|}{ Analysis of variance } \\
\hline Salinity & & $* * *$ & $*$ & $* *$ & $* * *$ & $* * *$ & $* * *$ & $* *$ & NS \\
\hline Time & & $* * *$ & NS & $*$ & $*$ & NS & NS & NS & NS \\
\hline Salinity $\times$ time & & $* * *$ & NS & NS & NS & NS & NS & NS & NS \\
\hline
\end{tabular}

${ }^{*, * *, * * *}$ Significant differences between means at the $5 \%, 1 \%$, and $0.1 \%$ level of probability. NS $=$ nonsignificant at $P=5 \%$. Means with different letters indicate significant differences $(P<0.05)$ by Tukey's test.

Table 5. Effect of salinity and time of salinization on tomato leaf mineral composition $\left(\mathrm{mmol} \cdot \mathrm{kg}^{-1} \mathrm{DW}\right)$.

\begin{tabular}{|c|c|c|c|c|c|c|}
\hline \multicolumn{2}{|c|}{ Treatments } & & & & & \\
\hline \multirow{2}{*}{$\begin{array}{l}\text { Salinization } \\
\text { time (DAT) }\end{array}$} & \multirow{2}{*}{$\begin{array}{c}\mathrm{EC} \\
\left(\mathrm{dS} \cdot \mathrm{m}^{-1}\right)\end{array}$} & \multicolumn{5}{|c|}{ Leaf mineral composition } \\
\hline & & $\mathrm{Cl}^{-}$ & $\mathrm{Na}^{+}$ & $\mathrm{K}^{+}$ & $\mathrm{Ca}^{2+}$ & $\mathrm{Mg}^{2+}$ \\
\hline \multirow[t]{4}{*}{16} & 2 (Control) & 101 & 44 & 470 & $532 \mathrm{~b}$ & 112 \\
\hline & 4 & 152 & 126 & 423 & $569 \mathrm{a}$ & 104 \\
\hline & 6 & 220 & 151 & 400 & $390 \mathrm{ef}$ & 102 \\
\hline & 8 & 293 & 205 & 373 & $307 \mathrm{~g}$ & 89 \\
\hline \multirow[t]{3}{*}{36} & 4 & 141 & 101 & 403 & $371 \mathrm{f}$ & 98 \\
\hline & 6 & 186 & 114 & 419 & $405 \mathrm{de}$ & 104 \\
\hline & 8 & 254 & 153 & 361 & $393 \mathrm{ef}$ & 113 \\
\hline \multirow[t]{3}{*}{66} & 4 & 138 & 99 & 435 & $462 \mathrm{c}$ & 99 \\
\hline & 6 & 177 & 114 & 381 & $425 \mathrm{~d}$ & 107 \\
\hline & 8 & 217 & 136 & 355 & 396 def & 107 \\
\hline \multicolumn{7}{|c|}{ Main Factor } \\
\hline \multirow[t]{3}{*}{ Salinity } & 4 & $144 \mathrm{c}$ & $109 \mathrm{c}$ & $420 \mathrm{a}$ & $467 \mathrm{a}$ & 100 \\
\hline & 6 & $194 \mathrm{~b}$ & $126 \mathrm{~b}$ & $400 \mathrm{~b}$ & $407 \mathrm{~b}$ & 104 \\
\hline & 8 & $255 \mathrm{a}$ & $165 \mathrm{a}$ & $363 c$ & $365 c$ & 103 \\
\hline \multirow[t]{3}{*}{ Time (DAT) } & 16 & $222 \mathrm{a}$ & $161 \mathrm{a}$ & 399 & 422 & 98 \\
\hline & 36 & $194 \mathrm{ab}$ & $123 \mathrm{~b}$ & 394 & 390 & 105 \\
\hline & 66 & $177 \mathrm{~b}$ & $116 \mathrm{~b}$ & 390 & 428 & 104 \\
\hline \multicolumn{7}{|c|}{ Analysis of variance ( $F$ value) } \\
\hline Salinity & & $* * *$ & $* * *$ & $* * *$ & $* * *$ & NS \\
\hline Time & & $* *$ & $* * *$ & NS & NS & NS \\
\hline Salinity $\times$ time & & NS & NS & NS & $* * *$ & NS \\
\hline
\end{tabular}

(data not shown). Internal and external BER are caused by a local $\mathrm{Ca}^{2+}$ deficiency in the distal placental fruit tissue (Cuartero and Fernandez-Muñoz, 1999). Salinity increases the incidence of BER by decreasing $\mathrm{Ca}^{2+}$ uptake (Adams and Ho, 1993). This means that the fruits from the highest trusses show a sink strength, with respect to the uptake of water and nutrients, weaker than for those from the lowest trusses, which makes them

\section{Literature Cited}

Adams, P. 1991. Effects of increasing the salinity of the nutrient solution with major nutrients or sodium chloride on the yield, quality and composition of tomatoes grown in rockwool. J. Hort. Sci. 66:201-207.

Adams, P. and L.C. Ho. 1989. Effects of constant and fluctuating salinity on the yield, quality and calcium status of tomatoes. J. Hort. Sci. 64:725-732.

Adams, P. and L.C. Ho. 1993. Effects of environment on the uptake and distribution of calcium in tomato and on the incidence of blossom-end rot. Plant and Soil 155:127-132.

Bangerth, F. and L.C. Ho. 1984. Fruit position and fruit sequence in a truss as factors determining final fruit size of tomato fruits. Ann. Bot. 53:315319.

Bertin, N. 1995. Competition for assimilates and fruit position affect fruit set in indeterminate greenhouse tomato. Ann. Bot. 75:55-65.

Cerdá, A., F.T. Bingham, and G. Hoffman. 1977. Interactive effect of salinity and phosphorus on sesame. Soil Sci. Soc. Am. J. 41:915-918.

Cuartero, J. and R. Fernandez-Muñoz. 1999. Tomato and salinity. Sci. Hort. 78:83-125.

Gough, C. and G.E. Hobson. 1990. A comparison of the productivity, quality, shelf-life characteristics and consumer reaction to the crop from cherry tomato plants growth at different levels of salinity. J. Hort. Sci. 65:431-439.

Hewitt, B.R. 1958. Spectrophotometric determination of total carbohydrate. Nature 182:246-247.

Kuehny, J.S. and B. Morales. 1998. Effects of salinity and alkalinity on Pansy and Impatiens in three different growing media. J. Plant Nutr. 21:10111023.

Lunin, J., M.H. Gallatin, and A.R. Batchelder. 1963. Saline irrigation of several vegetable crops at various growth stages. I. Effect on yields. Agron. J. 55:107-111.

Maas, E.V. and G.J. Hoffman. 1977. Crop salt tolerance-Current assessment. J. Irrig. Drin. Div. Am. Soc. Civ. Eng. 103:115-134.

Martínez, V., A. Cerdá, and F.G. Fernandez. 1987. Salt tolerance of four tomato hybrids. Plant and Soil 97:233-242.

Mitchell, J.P., C. Shennan, S.R. Grattan, and D.M. May. 1991a. Tomato fruits yields and quality under water deficit and salinity. J. Amer. Soc. Hort. Sci. 116:215-221.

Mitchell, J.P., C. Shennan, and S.R. Grattan. 1991b. Developmental changes in tomato fruit composition in response to water deficit and salinity. Physiol. Plant. 83:177-185.

Mizrahi, Y.,E. Taleisnik, V. Kagan-Zur, Y.Zohar, R. Offenbach, E. Matan, and R. Golan. 1988. A saline irrigation regime for improving tomato fruit quality without reducing yield. J. Amer. Soc. Hort. Sci. 113:202-205.

Petersen, K.K., J. Willumsen, and K. Kaack. 1998. Composition and taste of tomatoes as affected by increased salinity and different salinity sources. J. Hort. Sci. and Biotech. 73:205-215.

Shalhevet, J. and B. Yaron. 1973. Effects of soil and water salinity on tomato growth. Plant and Soil 39:285-399.

Sharaf, A.R. and G.E. Hobson. 1986. Effect of salinity on the yield and quality of normal and non ripening mutant tomatoes. Acta Hort. 190:175182.

SPSS Inc. 1985. 444 North Michigan Avenue, Chicago.

Van Genuchten, M.T. 1983. Analyzing crop salt tolerance data: model description and user's manual.USDA-ARS. Research Rep. 120. Washington D.C.

Voogt, W. 1988. The growth of beefsteak tomato as affected by $\mathrm{K} / \mathrm{Ca}$ ratios in the nutrient solution. Acta Hort. 222:155-165. 